\section{Inheritance of Powdery Mildew Resistance and Leaf Macrohair Density in Gerbera hybrida}

\author{
Wesley E. Kloos, ${ }^{1}$ Carol G. George, ${ }^{2}$ and Laurie K. Sorge ${ }^{3}$ \\ Department of Genetics, North Carolina State University, Raleigh, North \\ Carolina 27695-7614
}

Additional index words. Podosphaera fusca resistance, gerbera genetics, macrohairs, trichomes

\begin{abstract}
The cultivated gerbera daisy [Gerbera hybrida (G. jamesonii Bolus ex Adlam $\times G$. viridifolia Schultz-Bip)] often contracts powdery mildew (PM) when grown under conditions of high humidity. During field and greenhouse performance trials conducted with gerberas of the North Carolina State University collection, two half-sib field plants and two of their greenhouse-grown progeny were identified as being highly resistant to PM caused by Podosphaera (Sphaerotheca) fusca (Fr.) Blumer emend. Braun \& Takamatsu. These plants were also unusual in having smooth glossy leaves with very low numbers of bristle macrohairs (MHs) on the adaxial leaf surface compared to wild type. The primary objectives of this investigation were to determine the mode of inheritance of $\mathrm{PM}$ resistance and $\mathrm{MH}$ density traits and determine if there was a causal relationship between the phenotypes. Parental genotypes were determined by testcrosses to wild-type, PM-susceptible and MH-high-density leaf cultivars. For each trait, a series of crosses were made to produce $\mathrm{P}_{\mathrm{A}}, \mathrm{P}_{\mathrm{B}}, \mathrm{F}_{1}, \mathrm{~F}_{2}, \mathrm{BC}_{1 \mathrm{~A}}$, and $\mathrm{BC}_{1 \mathrm{~B}}$ progeny. Linkage relationships among $P M$ resistance and $\mathrm{MH}$ density loci were examined by testcrosses. Phenotypic segregation ratios suggested the presence of a dominant allele, Pmr1, determining PM resistance and an unlinked dominant allele, $M h d$, determining low density of adaxial bristle MHs and moderate reduction in abaxial smooth MHs. The Pmrl allele appeared to be incompletely dominant in some heterozygotes where one parent was from a highly PM susceptible background. Modifying genes may have some affect on the level of PM resistance or susceptibility. The Mhd allele appeared to be incompletely dominant in some heterozygotes. Segregation ratios indicated that the wild-type alleles were recessive to the PM-resistance and MH-low-density alleles and given the designation pmr 1 and $m h d$, respectively. Density of leaf MHs did not affect PM resistance.
\end{abstract}

Cultivated gerberas, given the provisional name Gerbera hybrida (Asteraceae), are diploids resulting from crosses of $G$. jamesonii $\times$ G. viridifolia (Bremer, 1994; Hansen, 1999). They are ornamentals widely used by florists and nurserymen throughout the world. Production in the United States has been mainly by growers in Florida and California (Rogers and Tjia, 1990). Development of disease resistant gerbera cultivars has progressed slowly due to lack of genetic information available on resistance to specific pathogens. One of the most common diseases of gerberas is powdery mildew (PM). It is caused mainly by Podosphaera (Sphaerotheca) fusca (Braun, 1995; Braun et al., 2002: Cunningham, 2003; Shin, 2000) and/or Golovinomyces (Erysiphe)

Received for publication 13 Oct. 2004. Accepted for publication $15 \mathrm{Jan}$. 2005. The authors thank Jeff Hauley, Lyla Kloos, Mathew Lemons, and Cecil Tarrant for their technical assistance and Brooks Johnson and Felix Jones for use of their land for growing plants in the field. The North Carolina Agricultural Research Service (Project No. NCO6463) provided funds for this study. The use of trade names in this publication does not imply endorsement by the NCARS of the products named, nor criticism of similar ones not mentioned.

${ }^{1}$ Professor, to whom reprint requests should be addressed; e-mail wesley_kloos@ncsu.edu.

${ }^{2}$ Research technician.

${ }^{3}$ Visiting scholar. cichoracearum (Alfieri et al., 1984; Amano, 1986; Braun, 1995; Braun et al., 2002; French, 1989; Grand, 1985). Powdery mildews are obligate biotrophic parasites. Infection by these organisms greatly diminishes gerbera plant and flower quality and ultimately affects plant vigor. PM occurs frequently on gerberas grown in the southeastern USA in greenhouses, nurseries, fields, and gardens where high humidity prevails for most of the growing season (Miller and Tjia, 1983). Infection is greatest during the cooler spring and fall months and when plants are crowded, diminishing air circulation. Heavy infection may reduce overwintering survival of plants growing in the field or garden (W.E. Kloos, unpublished data). Chemical control is a disease management option, but resistant cultivars provide a more economic and environmentally safe control strategy. Developing such cultivars should be feasible once those with durable resistance (i.e. cultivars maintaining resistance for at least 5 years prior to breeding) are identified and the mode of inheritance is understood.

$\mathrm{PM}$ is a serious disease of some other herbaceous ornamental species growing in humid climates (Braun 1995). P. fusca is a causal organism of PM in the calendula (Calendula officinalis L.), petunia (Petunia $\times$ hybrida Hort. Vilm.), African violet (Saintpaulia ionantha H. Wendl.), and verbena (Verbena $\times$ hybrida
Groenl. \& Ruempler)(Cunningham, 2003). G. cichoracearum produces PMin the chrysanthemum [Dendranthema $\times$ grandiflorum (Ramat.) Kitam.], dahlia (Dahlia pinnata Cav.) (Shin, 2000), monarda (Monarda didyma L.) (Bir and Hawke, 1999; Perry, 1999), and garden phlox (Phlox paniculata L.) (Bir and Conner, 2002; Taylor et al., 2002). Moderate to high levels of resistance have been observed in certain cultivars of African violets to the mildew Erysiphe orontii Cast. emend. Braun (Strider, 1980), Rieger elatior begonias (tuberous-rooted $\mathrm{Be}$ gonia L. species $\times$ Begonia socratrana) to $E$. orontii and G. cichoracearum (Strider, 1974), monarda to G. cichoracearum (Bir, 2000; Bir and Hawke, 1999), and the garden phlox to $G$. cichoracearum (Bir and Conner, 2002; Taylor et al., 2002). The genetic basis of resistance in these cultivars has not yet been determined. More recently, it has been shown that the high level of resistance of sweet pea hybrids Lathyrus oderatus L. $\times$ Lathyrus belinensis $\mathrm{L}$. to Erysiphe pisi DC was controlled by a single, dominant $R$ gene (Poulter et al., 2003). The mechanisms and genetics of PM resistance have been extensively studied in certain cereal and vegetable crops (Bélanger et al., 2002; Dreiseitl and Rashal, 2004; McCreight, 2003). Several major types of PM resistance have been identified among these hosts, including 1) pathogen race-specific resistance (hypersensitivity resistance response) that is usually short-term and determined by single dominant or semi-dominant $R$ genes (Goodman and Novacky, 1994; Hsam and Zeller, 2002; Jørgensen, 1994); 2) broad-spectrum, partial resistance or adult-plant resistance (APR) that is usually durable and inherited polygenically (Das and Griffey, 1995; Johnson, 1979; Jones and Davies, 1985); 3) broad-spectrum mlo resistance that is usually durable and controlled by recessive mlo alleles (Collins et al., 2002); and 4) broad-spectrum, systemic acquired resistance (SAR) activated systemically by site inoculation with necrogenic viral, bacterial, or fungal pathogens or applications of salicylic acid or certain other chemicals, the establishment of which induces the defense, pathogenesis-related (PR) protein genes (Salmeron et al., 2002; Ward et al., 1991). Cellular and molecular studies of cereal, vegetable, and arabidopsis host-mildew interactions are in the process of providing models for explaining the pathogenesis of infections (Bélanger et al., 2002; Vogel and Somerville, 2002).

During field and greenhouse performance trials of gerbera breeding lines, conducted in 1994 and 1995, we identified two half-sib field plants and their greenhouse-grown progeny that were highly resistant to PM by $P$. fusca. In addition to having a high level of resistance, these plants had smooth glossy leaves with very low numbers of bristle macrohairs (MHs) on the upper (adaxial) leaf surface, compared to the wild-type phenotype. We wondered if the glabrous (nearly hairless) condition affected the ability of the PM pathogen to colonize the adaxial leaf surface or was the association of resistance and reduced bristle $\mathrm{MH}$ density coincidental. The terms trichome and hair are synonymous. We have chosen to use the more 
recent term macrohair, as defined by Moose et al. (2004), to denote the visible hairs on the gerbera. An earlier related study had established that foliar trichomes served as infection sites in tomato (Lycopersicon esculentum Mill.) for the bacterial pathogen Corynebacterium michiganense (E.F.Sm.) H.L. Jens. (Layne, 1967). Young leaves, which had the highest trichome density, were most susceptible. Glabrous mutants having greatly reduced numbers or no leaf hairs have been identified in many cereal crops (Foster and Rutger, 1978; Gibson and Maiti, 1983; Kumar and Andrews, 1993; Leisle, 1974; Moose et al., 2004), but no studies examining a relationship of PM resistance and hair density have been reported.

The primary objectives of this study were to determine the mode of inheritance of PM resistance and $\mathrm{MH}$ density traits in the above gerbera plants and determine if there was a causal relationship between the phenotypes. We used a Mendelian genetic analysis designed to identify the major genes (loci) controlling these traits and evaluated linkage relationships (Griffiths et al., 1999).

\section{Materials and Methods}

Plant material. Abbreviated pedigrees of the powdery mildew-resistant (PMR), MHlow-density (MHLD) leaf plants 176 and 214 are as follows: Plant 176 [3 (unknown lineage) $\times 28(\mathrm{RDBC} \times \mathrm{OR} / \mathrm{YECR})]$; plant 214 [24 $(\mathrm{RDBCCR} \times \mathrm{VH} 1) \times 35(\mathrm{RDBC} \times 21)]$. Parent 28 of plant 176 and 35 of plant 214 were also highly resistant to PM and had the MHLD phenotype. Parent 3 of plant 176 was powdery mildew susceptible (PMS) and had wild-type, MH-high-density (MHHD) leaves. Parent 24 of plant 214 was MHLD; however it died prior to PM testing. Grandparents OR/YECR, VH1, and 21 were PMS-MHHD. RDBC, a shared grandparent of 176 and 214, and RDBCCR, a parent of 24, were MHLD but died prior to PM testing. Based on the similar phenotypes of plants 28 and 35, we suspect that the shared parent RDBC was PMR or, if not, produced some gametes carrying a gene(s) specifying resistance.

Plants 176 and 214 were both heterozygous for the semicrested flower trait (Kloos et al., 2004); 176 produced light salmon-yellow flowers with a yellow-green central disk and 214 produced dark red flowers with a brownblack central disk. They were crossed to a variety of cultivars collected by W.E. Kloos to introduce PM resistance into lines exhibiting different desirable traits. The cultivar lines were originally derived from seeds obtained from commercial sources and J. Harding (Dept. of Environmental Horticulture, Univ. of California, Davis) and plants obtained from various nurseries located in North Carolina, Florida, and California and from Roy Larson [Dept. of Horticultural Science, North Carolina State Univ. (NCSU), Raleigh]. By outcrossing, linebreeding (matings of half sibs or plants more distantly related within a line by single-seed descent), and recurrent selection over four generations we were able to obtain PMR gerberas representing the major flower types and colors and, in addition, demonstrate the stability of the gene(s) controlling resistance.

Plants used in the present study were part of the NCSU gerbera collection formed in 1996 (Kloos et al., 2004). In total, 35 PMR-MHLD, 39 PMR-MHHD, 17 PMS-MHLD, and 81 PMS-MHHD plants were used as parents in crosses to gain information on the inheritance of PM resistance and MH density. Of the 18 homozygous PMR parents, 16 were progeny from both 176 and 214 lineages, one was from the 176 and one was from the 214 lineage. Of the 56 heterozygous PMR parents, 26 were progeny from both 176 and 214 lineages, 12 were from the 176 and 18 were from the 214 lineages. An additional 34 MHLD and 49 MHHD plants, not tested for PM resistance, were used only as parents in crosses examining the inheritance of the MH density trait.

Genetic analysis. The genotype of each parent was determined by testcrosses (parent $\times$ wild type). It was assumed that the wild-type gerbera is PM susceptible and has MHHD leaves based on the very high proportion of these phenotypes found among cultivated Gerbera hybrida and the parental species. For each trait, a series of crosses were made to produce $\mathrm{P}_{\mathrm{A}}, \mathrm{P}_{\mathrm{B}}, \mathrm{F}_{1}, \mathrm{~F}_{2}, \mathrm{BC}_{1 \mathrm{~A}}$, and $\mathrm{BC}_{1 \mathrm{~B}}$ progeny. Linkage relationships of loci were examined by testcrosses. The chi-square test was used to interpret phenotypic ratios and quantify the various deviations expected by chance. Pollination and seed storage methods have been described previously (Kloos et al., 2004).

Cultivation. Cultural practices for breeding plants, seed germination, and seedlings have been described previously (Kloos et al., 2004). At 2 months of age, seedlings were transferred to standard $1500-\mathrm{cm}^{3}$ clay pots containing Metro Mix 200 in September for growth in the greenhouse with natural light or planted outdoors in April or May for growth in raised beds exposed to full sun. Growing temperatures in the greenhouse ranged from 20 to $40{ }^{\circ} \mathrm{C}$ day $/ 16$ to $24{ }^{\circ} \mathrm{C}$ night. Just before and during the PM assessment period (November through February) temperatures ranged from 20 to 30 ${ }^{\circ} \mathrm{C}$ day/ 16 to $20{ }^{\circ} \mathrm{C}$ night. The range of spring through fall outdoor growing temperatures was somewhat greater than that of the greenhouse. Just prior to and during the field and garden PMassessment period (late September through early November) temperatures ranged from 16 to $30{ }^{\circ} \mathrm{C}$ day/ 2 to $16{ }^{\circ} \mathrm{C}$ night. Potted plants received $6 \mathrm{~g}$ of $14 \mathrm{~N}-6.1 \mathrm{P}-11.6 \mathrm{~K}$ slow-release fertilizer (Osmocote; Scotts-Sierra Horticultural Products Co., Marysville, Ohio) per pot at 3 -month intervals. They also received $200-\mathrm{mL}$ applications of $12 \mathrm{~N}-24.0 \mathrm{P}-5.0 \mathrm{~K}$ liquid fertilizer (Super Bloom; Green Light, San Antonio, Texas) at $11.5 \mathrm{~g} \cdot \mathrm{L}^{-1}$ initiated when flower buds first appeared. Field and garden plants received twice the amount of fertilizer applied to potted plants, but at the same intervals. Potted plants were provided with about $400 \mathrm{~mL}$ of tap water daily. Field and garden plants were irrigated when necessary. Greenhouse culture was conducted during 1997, 1998, and 1999 in an NCSU greenhouse located in Raleigh (Wake County). Potted plants were placed about 15 $\mathrm{cm}$ apart in the greenhouse to maximize the humidity surrounding each plant and natural inoculation by indigenous mildews growing on segregating PMS and control PMS plants. To enhance natural inoculation by mildews, control PMS crosses were interspersed among the PMR $\times$ PMR and PMR $\times$ PMS crosses. Plants were grown in the greenhouse until April of the following year. Field culture was conducted during April through November 1997 in a field located in Cary, N.C. (Wake County), May 1997 to May 1998 and May 1998 to May 1999 in a field located in Sanford, N.C. (Lee County), and May 1998 to May 1999 in a garden in Apex (Wake County), N.C. The Cary and Apex sites were $10 \mathrm{~km}$ apart and these were located about $38 \mathrm{~km}$ from the Sanford site. In field plots, plants were arranged in three rows down the length of each raised bed. In the garden, plants were arranged in a series of rows filling four $183 \times 366 \times 48 \mathrm{~cm}$ (width $\times$ length $\times$ height) contained beds. Plants were spaced about $25 \mathrm{~cm}$ apart in the row and across from one another. Field and garden beds were about $80 \mathrm{~cm}$ apart. Control PMS $\times$ PMS crosses were interspersed with PMR $\times$ PMR and PMR $\times$ PMS crosses.

Disease assessment. PM severity and incidence on fully extended leaves was assessed by visual examination of leaf surfaces, noting the number and area of leaves affected, including the number of colonies present and extent of their sporulation. The resistance $(\mathrm{R})$ and susceptible (S) categories (infection ratings) were as follows: $\mathrm{R}_{0}=$ very resistant, no colonies of PM detected on any leaves; $\mathrm{R}_{1}=$ resistant, $<20$ small colonies/leaf with no or light sporulation and present on a few leaves; $\mathrm{R}_{2}=$ moderately resistant, 20 to 30 colonies/leaf with light sporulation and present on many leaves; $\mathrm{S}_{3}=$ moderately susceptible, colonies with moderate sporulation coalesced into large regions of about $50 \%$ to $75 \%$ of the adaxial leaf surface on many leaves; $\mathrm{S}_{4}=$ susceptible, colonies with abundant sporulation coalesced into large regions on $>75 \%$ of the adaxial leaf surface on nearly all leaves; and $\mathrm{S}_{5}=$ very susceptible, entire adaxial leaf surface covered with PM showing abundant sporulation on nearly all leaves, including some new leaves not yet fully extended. Assessments were initiated in October or November for plants grown in the field and garden and December or January for plants grown in the greenhouse at a time when all control PMS $\times$ PMS susceptible progeny showed evidence of infection. Observations continued at weekly intervals for 1 month and sporadically thereafter for an additional month. Progeny from crosses aimed at determining linkage relationships of the PM resistance and MH density genes, were observed through April of the following year, at a time when $\mathrm{MH}$ density was at a minimum in MHLD plants. The lower density facilitated identification of the MHLD phenotype and aided in showing if there were any associations of PMR with $\mathrm{MH}$ phenotypes. All parents and selected progeny, particularly those to be evaluated as future breeding stock, were assessed periodically in the fall for up to 5 years to evaluate the durability of PM resistance.

To compare PM severity and incidence 
resulting from laboratory inoculations with those of natural inoculations, 10 -cm-diameter discs cut from fresh detached leaves of breeding gerbera plants (8 parents and 93 of their progeny) were inoculated with $P$. fusca spores and the disease assessed in the laboratory of S. Leath (Dept. of Plant Pathology, NCSU). Assessments were made in August 2000 from plants growing outdoors in pots in full sun at the NCSU Horticultural Field Laboratory located in Raleigh. At that time no visible evidence of infection was seen on the leaves of PMR and PMS plants. Duplicate sets of 10 leaf discs from each of 2 fully expanded, detached leaves taken from each plant were placed on $0.5 \%$ water agar amended with 50 ppm benzimidazole in $19 \times 10 \times 1.5 \mathrm{~cm}$ plastic dishes (Leath and Heun, 1990). One set was inoculated and the other served as the un-inoculated control. Spores of $P$. fusca were produced naturally on PMS plant 5-14 (rating $\mathrm{S}_{5}$ ) grown at high humidity in a partial-shaded greenhouse. Fresh spores were taken from host leaves showing the most sporulation and then brushed onto the adaxial surface of leaf discs. To evaluate the natural inoculum and insure the presence of the major race(s) or genotype(s) of $P$. fusca infecting the host leaves, an attempt was not made to develop a monoculture taken from a single spore. However, future investigations aimed at studying the virulence of individual $P$. fusca races will require the use of monocul- ture inocula. Plates containing leaf discs were covered with a transparent lid and placed in a temperature-controlled growth chamber at 18 $\pm 1{ }^{\circ} \mathrm{C}$ under low light intensity for $14 \mathrm{~d}$. PM severity (extent of sporulation) and incidence (number of discs showing infection) were recorded at 5,10 , and $14 \mathrm{~d}$ post-inoculation. Based on our observations of 20 inoculated leaf discs/plant, we proposed a leaf disc infection rating (DIR) scale as follows: $0=$ none showing infection; $1=1$ to 3 discs showing mycelia with no or light sporulation; $2=4$ to 5 discs showing mycelia with light sporulation; $3=6$ to 16 discs showing moderate sporulation; $4=10$ to 16 discs showing abundant sporulation; and $5=$ all discs showing abundant sporulation.

The organism isolated from PM colonies growing on the surface of gerbera leaves was identified as $P$. fusca on the basis of their mycelium, conidia, conidiophore, and footcell morphology and the presence of fibrosin bodies in conidia, as viewed by light and phase contrast microscopy at 100, 200, and 400× magnification (Braun et al., 2002). Colony impressions were dispersed in $3 \%$ aqueous $\mathrm{KOH}$ and mounted on glass slides for microscopic examination. L.F. Grand and G. Abad (Department of Plant Pathology, NCSU) kindly instructed us in the identification. P. fusca was the only mildew species found on infected gerbera leaves sampled from 1995 to 2004.

Evaluation of macrohair density. Observa- tions on leaf bristle MHs were made in the spring and summer and at the same time as PM assessments in the fall (field and garden) or winter (greenhouse). Early in the investigation we noted that bristle MH density varied somewhat with the season. Several fully extended third, fourth, and fifth stage (order of leaf pairs following the first true leaf pair) leaves of each plant were examined with the unaided eye or a hand magnifying glass $(2.5 \times)$ and by touch when making an initial classification. The bristle $\mathrm{MH}$ was readily seen on the adaxial leaf surface. Plants were classified as follows: MHLD, glossy leaves with $<1$ to 5 bristle $\mathrm{MHs} / \mathrm{cm}^{2}$ and smooth to the touch; MH-intermediate-density (MHID), glossy leaves with 6 to 59 bristle $\mathrm{MH} / \mathrm{cm}^{2}$ and usually smooth to the touch; MHHD, leaves with 60 to 174 bristle $\mathrm{MH} / \mathrm{cm}^{2}$ and adaxial blade rough to the touch. There was a clear distinction between the MHLD and MHHD phenotypes and, with many comparisons, between MHID and MHHD phenotypes. The fourth- and fifth-stage leaves of parents and several of their $\mathrm{F}_{2}$ progeny, representing each of the $\mathrm{MH}$ density phenotypes and genotypes, were examined at 10 to $25 \times$ magnification using a stereomicroscope to estimate the density and size of MHs. For examination, each leaf was delineated into a series of three $1-\mathrm{cm}^{2}$ grids along the main axis and on either side of the midrib, equidistant from the margin and midrib,

Table 1. Phenotypic segregation ratios and powdery mildew infection ratings in crosses between gerbera plants with different combinations of $P m r 1$ alleles.

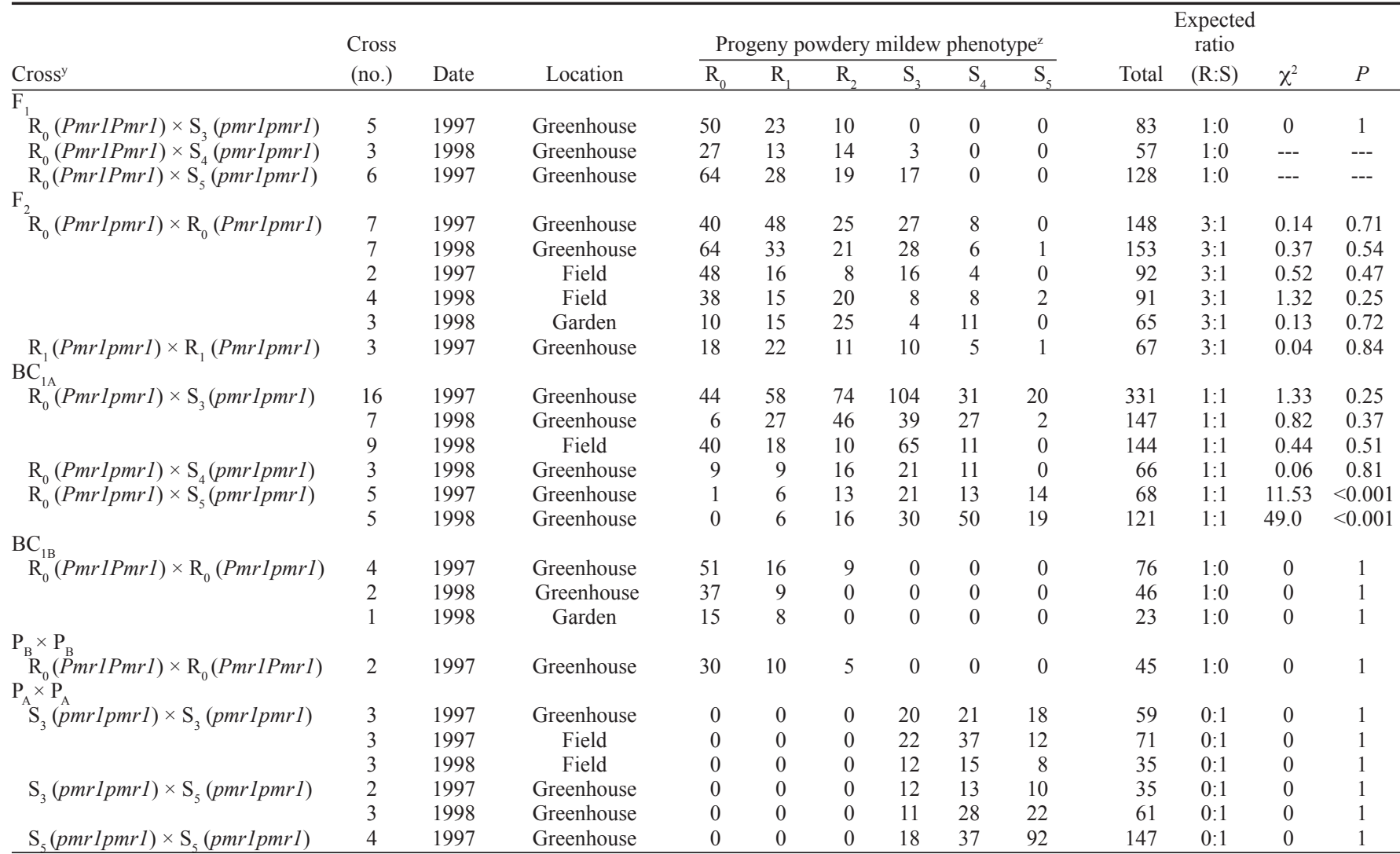

${ }^{2}$ Phenotypes: $\mathrm{R}_{0}=$ very resistant, no PM colonies detected on any leaves. $\mathrm{R}_{1}=$ resistant, $<20$ small colonies per leaf with no or light sporulation and present on a few leaves. $\mathrm{R}_{2}=$ moderately resistant, 20 to 30 colonies/leaf with light sporulation and present on many leaves. $\mathrm{S}_{3}=$ moderately susceptible, colonies with moderate sporulation coalesced into large regions on $50 \%$ to $75 \%$ of the adaxial leaf surface of many leaves. $\mathrm{S}_{4}=$ susceptible, colonies with abundant sporulation coalesced into large regions on $>75 \%$ of the adaxial leaf surface on nearly all leaves. $\mathrm{S}_{5}=$ very susceptible, entire adaxial leaf surface covered with powdery mildew showing abundant sporulation on nearly all of the leaves, including some of the new leaves not yet fully extended.

${ }^{y}$ Allelic symbols: Pmr1, powdery-mildew resistant; $p m r 1$, powdery-mildew susceptible. 
and three 1-cm long grids along the midrib. The types enumerated and measured included the adaxial-blade bristle MHs, abaxial-blade smooth MHs, adaxial-midrib MHs, and abaxial-midrib MHs. Flower stem and bract MHs were not counted, but their relative density was noted by making side-by-side comparisons to see if there was a correlation to the density of other MHs. The stem and bract MHs of MHHD plants were too numerous and intertwined with one another to count accurately. An analysis of variance was performed by Fischer's protected least significant difference (PLSD) (StatView version 5.0.1, SAS Institute, Cary, N.C.) for making pair-wise comparisons of the means of leaf $\mathrm{MH}$ numbers and lengths representing the different genotypes (courtesy of K. Olsen).

\section{Results and Discussion}

Genetic analysis of powdery mildew resistance. Many PMR plants showed no evidence of PM infection. Infected PMR plants were distinguished from PMS plants by the lack of confluent areas of PM infection on their leaves, and when individual PM colonies were present they showed light or no sporulation. The resistance and susceptible categories are described in Material and Methods. Testcrosses between very resistant $\left(\mathrm{R}_{0}\right)$ and moderately susceptible $\left(\mathrm{S}_{3}\right)$ gerberas of the NCSU collection produced progeny that were either PMR in a 1:0 ratio $(P=1)$ or PMR and PMS in a $1: 1$ ratio $\left(\chi^{2}=0.28\right.$ to $0.42, P=0.52$ to 0.60$)$ when grown in the greenhouse. These results suggest that PM resistance is under the control of a single dominant gene. The dominant gene was designated Pmrl (for powdery mildewresistant) and the wild-type, recessive gene for PM susceptibility was designated pmrl. The number $l$ was added as a suffix to the allelic designation $(\mathrm{Pmr})$ in anticipation of the discovery of additional PMR genes providing resistance to other races of $P$. fusca or other mildews, a pattern prevalent among other host species (Hsam and Zeller, 2002; Jahn et al., 2002). The original parents 214 and 176 were heterozygotes (Pmrlpmrl).

The pooled results of crosses between PMR and PMS gerberas representing different phenotypic and genotypic classes are given in Table 1. Segregation ratios of progeny from parents derived from separate 176 and 214 lineages or combined 176 and 214 lineages were not significantly different $(P>0.5)$. PMS parents $\left(\mathrm{P}_{\mathrm{A}}\right)$ when crossed to one another produced only PMS progeny. Crosses between moderately susceptible $\left(\mathrm{S}_{3}\right)$ parents produced $33 \% \mathrm{~S}_{3}$ and $23 \%$ very susceptible $\left(\mathrm{S}_{5}\right)$ progeny; whereas crosses between $\mathrm{S}_{5}$ parents produced $63 \% \mathrm{~S}_{5}$ and $12 \% \mathrm{~S}_{3}$ progeny. Perhaps more of the genes contributing to the $\mathrm{S}_{5}$ phenotype are homozygous compared to those contributing to the $\mathrm{S}_{3}$ phenotype and represent one of the limits defined by a hypothetical set of modifying, epistatic, or suppressor genes. Very resistant $\left(\mathrm{R}_{0}\right)$, PmrlPmrl parents $\left(\mathrm{P}_{\mathrm{B}}\right)$ when crossed to one another produced only PMR progeny, $67 \%$ of which were classified as $\mathrm{R}_{0}$.

Crosses between $\mathrm{R}_{0}$, PmrlPmrl and $\mathrm{S}_{3}$, pmrlpmrl parents produced only PMR $\mathrm{F}_{1}$ progeny. On the other hand, crosses between $\mathrm{R}_{0}$, PmrlPmrl and the more susceptible $\mathrm{S}_{4}$ and $\mathrm{S}_{5}$, pmrlpmrl parents produced 95 and $87 \%$ PMR $\mathrm{F}$ progeny, respectively and 5 and $13 \%$ PMS $\left(\mathrm{S}_{3}\right) \mathrm{F}_{1}$ progeny, respectively. Testcrosses indicated that the $\mathrm{S}_{3}$ progeny were heterozygotes $P m r 1 p m r l\left(\chi^{2}=0.36\right.$ to $0.66, P$ $=0.42$ to 0.55$)$. These results combined with the variation in resistance phenotypes $\left(\mathrm{R}_{0}, \mathrm{R}_{1}\right.$, $\mathrm{R}_{2}$ ) observed among PMR progeny suggested that the Pmrl allele exhibited some variability in dominance or expressivity. Clearly, the presumptive $P m r l$ gene has a major effect on the PM resistance phenotype, but it may not be the only factor. Other genes may be affecting the level of expression of Pmrl. Alternatively, more than one race or a more virulent mutant of $P$. fusca may be naturally infecting some of the above progeny, especially those exhibiting the susceptible $\mathrm{S}_{3}$ phenotype. Such an event would be expected to be infrequent, since all of the potted, gerbera breeding plants tested annually in this study demonstrated the same infection ratings throughout their lifetime ranging from 3 to at least 5 years.

The $\mathrm{F}_{2}$ generation from sib and half-sib pollinations segregated in the ratio of 3 PMR:1 PMS ( $P=0.25$ to 0.84 ) as would be expected if $\mathrm{PM}$ resistance was determined by a major, single gene (Pmrl) that was dominant to the gene $(p m r l)$ determining PM susceptibility. Crosses performed in 1997 and 1998 produced similar results. The $\mathrm{BC}_{1 \mathrm{~A}}$ generation produced from crosses between $\mathrm{R}_{0}$, Pmrlpmrl and $\mathrm{S}_{3}$ or $\mathrm{S}_{4}$, pmrlpmrl parents segregated in the expected ratio of 1 PMR:1 PMS $(P=0.25$ $0.81)$. Crosses between $\mathrm{R}_{0}$, Pmrlpmrl and $\mathrm{S}_{5}$, pmrlpmrl parents produced a 2- to 4-fold excess of PMS progeny, hence the hypothesis for an equal number of PMR and PMS progeny was rejected $(P<0.001)$ (Table 1$)$. It would not be unexpected to find a greater than equal number of PMS progeny considering that in an
$\mathrm{F}_{1}$, where one of the parents was $\mathrm{S}_{5}$, some of the progeny were classified as $\mathrm{S}_{3}$, Pmrlpmrl. The magnitude of excess PMS progeny was, nevertheless, surprising. In both generations, the expression or dominance of the Pmrl allele was lowest in the Pmrlpmrl heterozygote sharing an $\mathrm{S}_{5}$ background. The $\mathrm{BC}_{1 \mathrm{~B}}$ progeny from crosses between $\mathrm{R}_{0}$, PmrlPmrl and $\mathrm{R}_{0}$, Pmrlpmrl parents were PMR.

The PM infection ratings (phenotypes) of gerbera parents and progeny mentioned above were made on attached leaves of plants naturally inoculated by mildews. Comparisons of these ratings with those of detached leaf discs, directly inoculated with $P$. fusca in the laboratory, indicated that the phenotypes were correlated, though for most they were overlapping. For example, all $27 \mathrm{R}_{0}$ plants had a disc infection rating (DIR) of $0 ; 20$ and $9 \mathrm{R}_{1}$ plants had a DIR of 0 and 1 , respectively; $7,4,5$, and $1 R_{2}$ plants had a DIR of $0,1,2$, and 3 , respectively; 3,6 , and $7 \mathrm{~S}_{3}$ plants had a DIR of 2, 3, and 4, respectively; 2, 7, and $1 \mathrm{~S}_{4}$ plants had a DIR of 3, 4, and 5, respectively; and $1 \mathrm{~S}_{5}$ plant had a DIR of 4 and the other had a DIR of 5. Many of the un-inoculated (control) leaf discs were apparently naturally inoculated in the field prior to leaf detachment as indicated by their infection in the laboratory, even though the host plant appeared to be free of infection. Of the 47 plants with a DIR of 1 through 5,8 had uninfected control leaf discs, suggesting that the $P$. fusca inoculant was viable and infective. It followed that none of the control leaf discs from plants with a DIR of 0 were infected.

The type of PM resistance present in gerberas of the NCSU collection does not clearly resemble any of those described in cereal and vegetable crops (Bélanger et al., 2002). There was some similarity of Pmrl to R-genes in that a single dominant gene was the major gene controlling PM resistance and many of the PMR progeny exhibited a high level of resistance (Jørgensen, 1994). However, it could not be determined if the PMR resistance was race-specific, a key attribute of $R$ genes. To date, a reference collection of different races of $P$. fusca and G. cichoracearum, known to be pathogenic for $G$. hybrida, is not available for testing a spectrum of resistance. Although $P$. fusca was the only mildew species isolated from infected leaves sampled over the course of the study, one cannot be certain that they represented only one race or that other mildew species were not occasionally present on leaves. The gerbera progeny tested were

Table 2. Density and length of macrohairs on fully expanded leaves of the different gerbera $M h d$ genotypes.

\begin{tabular}{|c|c|c|c|c|c|c|c|c|c|}
\hline \multirow[b]{4}{*}{ Genotype $^{y}$} & \multicolumn{5}{|c|}{ Macrohair no. $/ \mathrm{cm}^{2 z}$} & & & & \\
\hline & & Adaxial & & & & \multicolumn{4}{|c|}{ Macrohair length (mm) } \\
\hline & \multicolumn{2}{|c|}{ Bristle } & & \multicolumn{2}{|c|}{ Abaxial } & \multicolumn{2}{|c|}{ Adaxial } & \multicolumn{2}{|c|}{ Abaxial } \\
\hline & Summer & Winter & $\overline{\text { Midrib }}$ & Smooth & Midrib & Bristle & Midrib & Smooth & Midrib \\
\hline MhdMhd & $0.3 \pm 0.5$ & $4 \pm 4 a^{x}$ & $28 \pm 15$ & $79 \pm 17$ & $49 \pm 15$ & $0.5 \pm 0.1$ & $3.2 \pm 0.8$ & $1.1 \pm 0.2$ & $2.9 \pm 0.4$ \\
\hline Mhdmhd & $2 \pm 2$ & $18 \pm 14 \mathrm{~A}$ & $29 \pm 14$ & $120 \pm 48$ & $42 \pm 12$ & $0.5 \pm 0.2$ & $3.2 \pm 0.8$ & $1.1 \pm 0.3$ & $2.9 \pm 0.6$ \\
\hline$m h d m h d$ & $103 \pm 30^{\text {**** }}$ & $111 \pm 33^{* * * *}$ & $48 \pm 16$ & $205 \pm 77^{* * * *}$ & $57 \pm 26$ & $0.7 \pm 0.2$ & $3.3 \pm 0.4$ & $1.3 \pm 0.3$ & $3.2 \pm 0.4$ \\
\hline
\end{tabular}

${ }^{2}$ Data represent the mean and standard deviation of the macrohair $(\mathrm{MH})$ number $/ \mathrm{cm}^{2}$.

y Allelic symbols: $M h d$, low density of bristle $\mathrm{MH}$ on adaxial leaf blade; $m h d$, high density of bristle $\mathrm{MH}$ on adaxial leaf blade.

${ }^{x}$ Within columns, means followed by a triple asterisk are significantly different at $P<0.0001$. Between the bristle summer and winter columns, means followed by the lowercase letter a are significantly different at $P<0.05$ and by an uppercase letter A are significantly different at $P<0.0001$. Pair-wise comparisons of the means were tested by an analysis of variance performed by Fischer's protected least significant difference (PLSD). 
grown in two nearly adjacent counties (Wake and Lee) in North Carolina. In future studies, the level of PM resistance should be tested in PmrlPmrl and Pmrlpmrl plants growing in more widely separated localities, where the likelihood of infection by other $P$. fusca races and/or other mildew species with different virulence genes would be increased. Unlike the usual short-term resistance observed in other plant species carrying $R$ genes, the PMR gerbera breeding plants tested and grown in Wake County demonstrated durable PM resistance for at least 5 years. This feature is more characteristic of broad-spectrum resistance like that observed for partial resistance (Jones and Davies, 1985) or mlo resistance (Collins et al., 2002) in cereals. However, PM resistance in the gerbera was different from the above examples of broad-spectrum resistance in that it was mainly determined by a single dominant gene and not by multiple genes with an additive effect or by a single recessive gene, respectively. Furthermore, resistance did not increase with the age of the plant and older leaves were more susceptible than younger ones. Could it be that the durability observed among PMR gerbera in this study was the consequence of a challenge by only one or, at most, a few closely related races of $P$. fusca rather than an indication of a broad-spectrum resistance? Studies investigating the chronology of the PM infection process, including developments at the cellular and molecular levels, should provide additional insight into the classification of PM resistance found in the NCSU gerbera population.

It was noteworthy that PMR gerberas growing in the field were generally frost-resistant, showing little or no leaf damage at frost (1 to $2{ }^{\circ} \mathrm{C}$ ) or moderately freezing temperatures ( -3 to $0{ }^{\circ} \mathrm{C}$ ); whereas PM-infected PMS gerberas showed extensive leaf damage at these temperatures, presumably due to the structural damage of tissue already compromised by widespread mildew penetration and subsequent colonization.

Descriptions of macrohair types and macrohair density phenotypes. Several types of prominent MHs were observed on the gerbera leaf surface. There did not appear to be any microhairs. The density and length of each MH type for each of the Mhd genotypes are given in Table 2. Adaxial bristle MHs were very stiff and straight or slightly curved. Adaxial midrib MHs were long and straight or kinked, with most of the length almost parallel to the leaf surface. Abaxial smooth MHs were soft and usually curled or twisted (coiled) along their length and difficult to measure. Abaxial mid-rib (and vein) MHs were soft, long, and straight, kinked, or curled. The MHLD phenotype was associated with a marked reduction in adaxial bristle MHs ranging from $1 \mathrm{MH} / 6 \mathrm{~cm}^{2}$ to 5 $\mathrm{MHs} / \mathrm{cm}^{2}$ during the months April through August and 3 to $62 \mathrm{MHs} / \mathrm{cm}^{2}$ during the months September through March. By comparison, the wild-type (MHHD) phenotype was characterized by a range of 60 to $174 \mathrm{MHs} / \mathrm{cm}^{2}$ and showed no seasonal effect. The MHLD phenotype was also associated with a somewhat lower density of abaxial smooth MHs (53 to $252 \mathrm{MHs} / \mathrm{cm}^{2}$ ) compared to the wild type ( 78 to $346 \mathrm{MHs} / \mathrm{cm}^{2}$ ). There was also a slight reduction in the number of adaxial midrib MHs and stem and bract MHs in MHLD plants. Sütterlin and van Lenteren (1997), studying the effect of hairiness of gerbera leaves on searching efficiency of the parasitoid Encarsia formosa Gahan determined that the mean abaxial hair(or $\mathrm{MH})$ density ranged from 80 to $363 \mathrm{MHs} / \mathrm{cm}^{2}$ for 9 different gerbera cultivars and was 1,041 $\mathrm{MHs} / \mathrm{cm}^{2}$ for 'Party'.

Genetic analysis of leaf bristle macrohair density. Testcrosses between different MHLD and MHHD gerberas produced progeny that were either in a ratio of 1 MHLD/MHID:0 MHHD or 1 MHLD/MHID:1 MHHD $\left(\chi^{2}=\right.$ 0.14 to $0.36, P=0.55$ to 0.71 ). These results suggested that the MHLD/MHID phenotype was under the control of a single dominant gene. The dominant gene was designated $M h d$ (for macrohair density) and the wild-type, recessive gene $m h d$. Original parent 214 was a homozygote (MhdMhd) and parent 176 was a heterozygote $(M h d m h d)$. The pooled results of crosses between MHLD and MHHD gerberas representing each phenotypic and genotypic class are given in Table 3 . Homozygous $m h d$ parents $\left(\mathrm{P}_{\mathrm{A}}\right)$ when crossed to one another produced only MHHD progeny. The progeny of crosses among homozygous Mhd parents $\left(\mathrm{P}_{\mathrm{B}}\right)$ were lost as a result of flooding. In the spring and summer, $92 \%$ of the $F_{1}$ progeny exhibited the MHLD phenotype and $8 \%$ the MHID phenotype. In the fall and winter, the leaves of some of the progeny from these, and crosses planted in the fall, exhibited a higher MH density. Of the $F_{1}$ progeny examined at this time, $33 \%$ had the MHID phenotype and $9 \%$ the low range of the MHHD phenotype, although those tested were Mhdmhd heterozygotes $\left(\chi^{2}=0.19\right.$ to $0.40, P=0.53$ to 0.66$)$. It appears that the expression of the dominant Mhd allele was incomplete or partially suppressed in some of the heterozygotes in the fall and winter and in fewer numbers during all seasons. The original parent 214 and its homozygous $M h d$ progeny that were parents in the above crosses showed no or only a slight seasonal effect on $\mathrm{MH}$ density. The influence of photoperiod and temperature on expression was not investigated in this study.

The $F_{2}$ progeny phenotypes examined in the spring and summer segregated in a ratio 3 MHLD/MHID:1 MHHD $(P=0.72)$ as would be expected if the MHLD trait was determined by a single gene (Mhd) that was dominant to the wild-type gene ( $m h d)$. In the fall and winter, progeny from these, and crosses planted in the fall, had a slightly higher proportion of plants exhibiting the MHID and MHHD phenotypes compared to those examined in the spring and summer; however, the expected 3 MHLD/ MHID:1 MHHD ratio was acceptable, albeit at a lower probability $(P=0.15)$.

The $\mathrm{BC}_{1 \mathrm{~A}}$ generation segregated as expected in a ratio of $1 \mathrm{MHLD} / \mathrm{MHID}: 1 \mathrm{MHHD}(P=$ $0.69)$ when progeny were examined in the spring and summer. This hypothesis was conditional upon the season; in the fall and winter it was rejected $(P=0.01)$. At this time, progeny segregated in a ratio of 1 MHLD/MHID:1.2 MHHD. The excess of MHHD plants was not entirely unexpected, since it was known that $\mathrm{MH}$ density might increase during fall and winter. The original parent 176 and $46 \%$ of the Mhdmhd heterozygotes (progeny of 176 and/or

Table 3. Phenotypic segregation ratios resulting from crosses between gerbera plants with different combinations of Mhd alleles.

\begin{tabular}{|c|c|c|c|c|c|c|c|c|c|}
\hline Cross & Season & $\begin{array}{l}\text { Cross } \\
\text { (no.) }\end{array}$ & \multicolumn{3}{|c|}{ Progeny macrohair density ${ }^{z}$} & \multicolumn{3}{|c|}{$\begin{array}{l}\text { Expected } \\
\text { ratio }\end{array}$} & $P$ \\
\hline \multicolumn{10}{|c|}{ (1) } \\
\hline \multicolumn{10}{|l|}{$\mathrm{F}_{2}$} \\
\hline MH-low-density $(M h d m h d)$ & Spring-summer & 10 & 109 & 10 & 37 & 156 & $3: 1$ & 0.13 & 0.72 \\
\hline$\times$ MH-low-density $(M h d m h d)$ & Fall-winter & 10 & 140 & 26 & 68 & 234 & $3: 1$ & 2.06 & 0.15 \\
\hline$\times$ MH-high-density $(m h d m h d)$ & Fall-winter & 35 & 182 & 123 & 375 & 680 & $1: 1$ & 7.21 & 0.01 \\
\hline \multicolumn{10}{|l|}{$\mathrm{BC}_{\mathrm{BB}}$} \\
\hline MH-low-density (MhdMhd) & Spring-summer & 7 & 110 & 16 & 0 & 126 & 1:0 & 0 & 1 \\
\hline$\times$ MH-low-density $(M h d m h d)$ & Fall-winter & 3 & 63 & 16 & 4 & 83 & $1: 0$ & --- & --- \\
\hline \multicolumn{10}{|l|}{$\mathrm{P}_{\mathrm{A}} \times \mathrm{P}_{\mathrm{A}}$} \\
\hline MH-high-density $(m h d m h d)$ & Spring-summer & 78 & 0 & 0 & 1522 & 1522 & $0: 1$ & 0 & 1 \\
\hline$\times$ MH-high-density $(m h d m h d)$ & Fall-winter & 15 & 0 & 0 & 312 & 312 & $0: 1$ & 0 & 1 \\
\hline
\end{tabular}

${ }^{\mathrm{z}}$ Macrohair (MH) phenotypes: MH-low-density (MHLD), adaxial leaf blade has $<1$ to 5 bristle $\mathrm{MHs} / \mathrm{cm}^{2}$ and is glossy and smooth to the touch; MH-intermediate-density (MHID), adaxial leaf blade has 6 to 59 bristle $\mathrm{MHs} / \mathrm{cm}^{2}$ and is glossy and usually smooth to the touch (those tested were $M h d m h d$ heterozygotes); MH-high-density (MHHD), adaxial leaf blade has 60 to 174 bristle $\mathrm{MHs} / \mathrm{cm}^{2}$ and is rough to the touch. 
214) that served as parents in the above crosses showed a transition from MHLD to MHID in the fall and winter, supporting the hypothesis that $M h d$ dominance was incomplete in certain plants at that time. $\mathrm{BC}_{1 \mathrm{~B}}$ progeny exhibited only MHLD and MHID phenotypes during the spring and summer; whereas $5 \%$ exhibited the low range of the MHHD phenotype during the fall and winter.

Linkage analysis of the Pmrl and Mhd loci. Linkage relationships of genes were analyzed by four testcrosses (PmrlpmrlMhdmhd $\times$ pmrlpmrlmhdmhd), where the PMR-MHLD heterozygote parent had allelic combinations in trans or repulsion (each parent of the heterozygote providing one dominant and one recessive gene)(Pmrlmhd/pmrlMhd). The phenotypes segregated as 40 PMR-MHLD/MHID, 35 PMR-MHHD, 33 PMS-MHLD/MHID, and 38 PMS-MHHD in a $1: 1: 1: 1$ ratio $\left(\chi^{2}=0.78\right.$, $P=0.85)$. This ratio indicated that the Pmrl and $M h d$ genes segregated independently and consequently were not linked. Their phenotypes showed no causal relationship. P. fusca infection was not affected by leaf MH density, since in the testcross progeny there was an equal probability that an MHLD/MHID or MHHD plant would be classified as PMS or PMR.

This study examined the inheritance of PM resistance and low bristle $\mathrm{MH}$ density in the cultivated gerbera $G$. hybrida. The two major putative genes controlling these traits were identified by a Mendelian genetic analysis and found to be unlinked. Whereas Pmrl appeared to be a major gene controlling PM resistance based on the $\mathrm{F}_{2}$ and certain $\mathrm{F}_{1}$ and $\mathrm{BC}$ segregation ratios, the model was not fully revealed. When the PMS parent in the cross was $\mathrm{S}_{5}$ there was a departure of $\mathrm{F}_{1}$ and $\mathrm{BC}_{1 \mathrm{~A}}$ segregation ratios from those expected. We expect that these findings will provide preliminary information for guiding future PM resistance research on G. hybrida. The spectrum of Pmrl resistance needs to be surveyed by testing plants with a variety of mildew species and races before one can conclude that this allele will give commercial growers a durable, and therefore beneficial, resistance. It will also be important to examine gerbera-mildew interactions taking place during the course of infection and determine at what stage(s) the resistance phenotype interferes with the pathogen. As a separate issue, gerberas with the MHLD phenotype have attractive smooth, glossy leaves that might facilitate their marketing as pot, cottage garden, or landscape plants. Their reduction in leaf MHs might facilitate the use of biological control measures for insect control.

\section{Literature Cited}

Alfieri, Jr., S.A., K.R. Langdon, C. Wehlburg, and J.W. Kimbrough. 1984. Index of plant diseases in Florida. Fla. Dept. Agr. Consumer Serv. Div. of Plant Ind. Bul. 11 (revised).

Amano, K. 1986. Host range and geographical distribution of the powdery mildew fungi. Jpn. Sci. Soc. Press, Tokyo.
Bélanger, R.R., W.R. Bushnell, A.J. Dik, and T.L.W. Carver (eds.). 2002. The powdery mildews. A comprehensive treatise. Amer. Phytopathol. Soc., St. Paul., Minn.

Bir, R.E. 2000. Mildew resistance in monarda NMPRO 16:67-70.

Bir, R.E. and J.L. Conner. 2002. Powdery mildew resistance in garden phlox. S. Nursery Assn. Res. Conf. 47:199-201.

Bir, R.E. and R. Hawke. 1999. Monarda mildew resistance. Proc. Intl. Plant Propagators Soc. 49:394-396.

Braun, U. 1995. The powdery mildews (Erysiphales) of Europe. G. Fischer Verlag, Jena, Germany.

Braun, U., R.T.A. Cook, A.J. Inman, and H.-D. Shin. 2002. The taxonomy of the powdery mildew fungi, p. 13-55. In: R.R. Bélanger, W.R. Bushnell, A.J. Dik, and T.L.W. Carver (eds.). The powdery mildews. A comprehensive treatise. Amer. Phytopathol. Soc., St. Paul, Minn.

Bremer, K. 1994. Asteraceae, cladistics and classification. Timber Press, Portland, Ore.

Collins, N.C., A. Sadanandom, and P. SchulzeLefert. 2002. Genes and molecular mechanisms controlling powdery mildew resistance in barley, p. 134-145. In: R.R. Bélanger, W.R. Bushnell, A.J. Dik, and T.L.W. Carver (eds.). The powdery mildews. A comprehensive treatise. Amer. Phytopathol. Soc., St. Paul, Minn.

Cunningham, J. 2003. Pathogenic fungi on introduced plants in Victoria. A host list and literature guide for their identification. Dept. Primary Industries Res., Victoria.

Das, M.K. and C.A. Griffey. 1995. Gene action for adult plant resistance to powdery mildew in wheat. Genome 38:277-282.

Dreiseitl, A. and I. Rashal. 2004. Powdery mildew resistance genes in Latvian barley varieties. Euphytica 135:325-332.

Foster, K. and J. Rutger. 1978. Independent segregation of semi-dwarfing genes and a gene for pubescence in rice. Heredity 69:137-138.

French, A.M. 1989. California plant disease host index. Calif. Dept. Food Agr., Sacramento.

Gibson, P. and R. Maiti. 1983. Trichomes in segregating generations of Sorghum matings: Inheritance of presence and density. Crop Sci. 23:73-75.

Goodman, R.N. and A.J. Novacky. 1994. The hypersensitivity reaction in plants to pathogens: a resistance phenomenon. Amer. Phytopathol. Soc., St. Paul, Minn.

Grand, L.F. 1985. North Carolina plant disease index. N.C. Agr. Res. Serv. Tech. Bul. 240:1-157.

Hansen, H.V. 1999. A story of the cultivated Gerbera. The New Plantsman (Royal Hort. Soc.) 6:85-95.

Hsam, S.L.K. and F.J. Zeller. 2002. Breeding for powdery mildew resistance in common wheat (Triticum aestivum L.), p. 219-238. In: R.R. Bélanger, W.R. Bushnell, A.J. Dik, and T.L.W. Carver (eds.). The powdery mildews. A comprehensive treatise. Amer. Phytopathol. Soc., St. Paul, Minn.

Jahn, M., H.M. Munger, and J.D. McCreight. 2002. Breeding cucurbit crops for powdery mildew resistance, p. 239-248. In: R.R. Bélanger, W.R. Bushnell,A.J.Dik, and T.L.W. Carver(eds.). The powdery mildews. A comprehensive treatise. Amer. Phytopathol. Soc., St. Paul, Minn.

Johnson, R. 1979. The concept of durable resistance. Phytopathology 69:198-199.

Jones, I.T. and I.J.E.R. Davies. 1985. Partial resistance to Erysiphe graminis hordei in old European barley varieties. Euphytica 34:499-507.
Jørgensen, J.H. 1994. Genetics of powdery mildew resistance in barley. Critical Rev. Plant Sci. 13:97-119.

Kloos, W.E., C.G. George, and L.K. Sorge. 2004. Inheritance of the flower types of Gerbera hybrida. J. Amer. Soc. Hort. Sci. 129:802-810.

Kumar, K. and D. Andrews. 1993. Genetics of qualitative traits in pearl millet: A review. Crop. Sci. 33:1-20.

Layne, R.E.C. 1967. Foliar trichomes and their importance as infection sites for Corynebacterium michiganense on tomato. Phytopathology57:981-985.

Leath, S. and M. Heun. 1990. Identification of powdery mildew resistance genes in cultivars of soft red winter wheat. Plant Dis. 74:747-752.

Leisle, D. 1974. Genetics of leaf pubescence in wheat. Crop. Sci. 14:173-174.

McCreight, J.D. 2003. Genes for resistance to powdery mildew races 1 and 2 U.S. in melon PI313970. HortScience 38:591-594.

Moose, S.P., N. Lauter, and S.R. Carlson. 2004. The maize macrohairless 1 locus specifically promotes leaf blade macrohair initiation and responds to factors regulating leaf identity. Genetics 166:1451-1461.

Perry, L.P. 1999. Powdery mildew on phlox and monarda. J. Soc. Municipal Arborists 35:14.

Poulter, R., L. Harvey, and D.J. Burritt. 2003. Qualitative resistance to powdery mildew in hybrid sweet peas. Euphytica 133:349-358.

Rogers, M.N. and B.O. Tjia. 1990. Gerbera production for cut flowers and pot plants. Timber Press, Portland, Ore.

Salmeron, J., B. Vernooij, K. Lawton, C. Kramer, C. Frye, M. Oostendorp, G. Knauf-Beiter, and T. Staub. 2002. Powdery mildew control through transgenic expression of antifungal proteins, resistance genes, and systemic acquired resistance, p. 268-287. In: R.R. Bélanger, W.R. Bushnell, A.J.Dik, and T.L.W. Carver (eds.). The powdery mildews. A comprehensive treatise. Amer. Phytopathol. Soc., St. Paul, Minn.

Shin, H.-D. 2000. Erysiphaceae of Korea. Natl. Inst. Agr. Sci. Technol., Suwon, Korea.

Strider, D.L. 1974. Resistance of Rieger elatior begonias to powdery mildew and efficacy of fungicides for control of the disease. Plant Dis. Rpt. 58:875-878.

Strider, D.L. 1980. Resistance of African violet to powdery mildew and efficacy of fungicides for control of the disease. Plant Dis. 64:188-190.

Sütterlin, S. and J.C. van Lenteren. 1997. Influence of hairiness of Gerbera jamesonii leaves on the searching efficiency of the parasitoid Encarsia formosa. Biol. Control 9:157-165.

Taylor, E., R. Cartwright, J. Robbins, G. Klingaman, and J. Lindstrom. 2002. Evaluation of Phlox paniculata L. cultivars for susceptibility to powdery mildew. S. Nursery Assn. Res. Conf. 47:194-198.

Vogel, J. and S. Somerville. 2002. Powdery mildew of Arabidopsis: a model system for host-parasite interactions, p. 161-168. In: R.R. Bélanger, W.R. Bushnell,A.J.Dik, and T.L.W.Carver(eds.). The powdery mildews. A comprehensive treatise. Amer. Phytopathol. Soc., St. Paul, Minn.

Ward, E.R., S.J. Uknes, S.C. Williams, S.S. Dincher, D.L. Wiederhold, D.C. Alexander, P. Ahl-Goy, J.-P. Métraux, and J.A. Ryals. 1991. Coordinate gene activity in response to agents that induce systemic acquired resistance. Plant Cell 3:1085-1094. 